\title{
Surviving the Global Financial Crisis: Foreign Ownership and Establishment Performance
}

\section{Citation}

Alfaro, Laura, and Maggie Chen. "Surviving the Global Financial Crisis: Foreign Ownership and Establishment Performance." American Economic Journal: Economic Policy 4, no. 3 (August 2012): 30-55.

\section{Published Version}

https://www.aeaweb.org/articles.php?doi=10.1257/pol.4.3.30

\section{Permanent link}

http://nrs.harvard.edu/urn-3:HUL.InstRepos:16422768

\section{Terms of Use}

This article was downloaded from Harvard University's DASH repository, and is made available under the terms and conditions applicable to Open Access Policy Articles, as set forth at http:// nrs.harvard.edu/urn-3:HUL.InstRepos:dash.current.terms-of-use\#OAP

\section{Share Your Story}

The Harvard community has made this article openly available.

Please share how this access benefits you. Submit a story.

Accessibility 


\title{
Surviving the Global Financial Crisis: Foreign Ownership and Establishment Performance*
}

\author{
Laura Alfaro ${ }^{\dagger}$ \\ Harvard Business School and NBER George Washington University \\ Maggie Chen ${ }^{\ddagger}$
}

March 2011

\begin{abstract}
We examine the differential response of establishments to the recent global financial crisis with particular emphasis on the role of foreign ownership. Using a worldwide establishment panel dataset, we investigate how multinational subsidiaries around the world responded to the crisis relative to local establishments. We find that, first, multinational subsidiaries fared on average better than local counterfactuals with similar economic characteristics. Second, among multinational subsidiaries, establishments sharing stronger vertical production and financial linkages with parents exhibited greater resilience. Finally, in contrast to the crisis period, the effect of foreign ownership and linkages on establishment performance was insignificant in non-crisis years.
\end{abstract}

JEL codes: F2, F1

Key words: global financial crisis, establishment response, foreign ownership, production linkage, financial linkage

${ }^{*}$ We are deeply grateful to the editor Alan Auerbach and two anonymous referees for many valuable comments and suggestions. We also thank James Harrigan, James Markusen, Ariell Reshef, and session and seminar participants at the American Economic Association Meeting, the Midwest International Economics Group Meeting, the LACEA Trade, Integration and Growth Network Meeting, University of Virginia, and IMF for helpful feedback. We are grateful to Dun \& Bradstreet and Dennis Jacques for helping with the D\&B dataset and HBS and GW CIBER for financial support.

${ }^{\dagger}$ Email: lalfaro@hbs.edu; Phone: 617-495-7981.

${ }^{\ddagger}$ Email: xchen@gwu.edu; Phone: 202-994-0192. 


\section{Introduction}

In 2007-2008, the world economy entered the deepest financial crisis since World War II. Countries around the globe witnessed major declines in output, employment, and trade. GDP in industrial countries fell by 4.5 percent while average GDP growth in emerging economies dropped from 8.8 percent in 2007 to 0.4 percent. The unemployment rate rose to 9 percent across OECD economies, and reached double digits in a mix of industrial and developing nations. World trade volume plummeted by over 40 percent in the second half of 2008 , collapsing at a rate that outpaced the fall of total output.

The severity of what has been labeled as the Global Financial Crisis led many economists to explore its macro patterns and causes. Rose and Spiegel (2010a, b), for example, investigate the potential causes for the differential extent of the crisis across countries. Using a large country-level dataset, they do not find international trade and financial linkages and other major economic indicators to be clearly associated with incidences of the crisis. Eaton et al. (2009), Levchenko, Lewis and Tesar (2010), and Chor and Manova (2011), among others, examine the potential causes of the great trade collapse, a phenomenon that received particular attention, and find, respectively, manufacturing demand, vertical specialization, and credit conditions to play important roles. ${ }^{1}$

Less explored in this debate is the pattern of micro economic responses to the crisis. ${ }^{2}$ In this paper, we examine the differential performance of establishments during the global crisis with particular emphasis on the role of foreign ownership. We investigate how foreign ownership affected establishments' resilience to the negative economic shocks using a worldwide establishment panel dataset that reports detailed operation, location, and industry information of over 12 million establishments in 2005-2008. We exploit how multinational corporation (MNC) subsidiaries around the world responded to the crisis relative to local establishments and the underlying mechanisms that led to the differential impact. This question is central to ongoing policy debates over the role of foreign direct investment (FDI) in economic growth and volatility. For many countries, such as Ireland, Slovakia, Singapore, and Malaysia, which have heavily relied on FDI as an engine of economic growth, there are increasing concerns that FDI is more volatile than domestic investments and renders countries greater economic vulnerabilities especially during economic crises.

Evaluating the role of foreign ownership during economic crises poses several challenges. First, it is difficult to disentangle the effect of foreign ownership from other establishmentlevel characteristics such as size and productivity and macroeconomic factors such as market

\footnotetext{
${ }^{1}$ Baldwin and Evenett (2009) compile some of the leading explanations.

${ }^{2}$ One exception is Tong and Wei (2009), who examine whether the volume and composition of capital flows affected the degree of credit crunches faced by a sample of emerging-economy manufacturing firms in the recent crisis. See Section 2 for an overview of this study and other papers, such as Alvarez and Görg (2007) and Desai, Foley and Forbes (2008), that explore the role of foreign ownership in establishment responses to past regional economic downturns and currency depreciations.
} 
demand and credit conditions. Second, why foreign ownership could lead to differential establishment performance often remains unclear. Different aspects of foreign ownership can exert sharply different, and even opposing, impact on establishment performance. For example, the ability of multinationals to shift production across countries can lead to more volatile performance while market diversification can lend stronger stability. Assessing only the average effect of foreign ownership can fail to capture these different mechanisms. Third, foreign ownership can affect establishment performance in both crisis and non-crisis periods. It is important to separate the general effect of foreign ownership from its impact on establishments' responses to negative economic shocks.

To disentangle the effect of foreign ownership from the effects of other establishment and macroeconomic factors, we adopt in our analysis a matching technique that creates a missing counterfactual for each MNC subsidiary. The matching pairs each MNC subsidiary with a local establishment that shares similar attributes and operates in the same country and industry. Similarity is determined based on establishment-level economic characteristics that have explanatory power in explaining establishments' foreign ownership status. Matching on the basis of characteristic similarity helps control for observable and unobservable differences between MNC subsidiaries and local establishments. Drawing the match from the same country and industry helps control for macroeconomic factors. The effect of foreign ownership is hence inferred from the divergence in the performance paths between MNC subsidiaries and their local matches.

To shed light on why foreign ownership could lead to divergent performance between MNC subsidiaries and local competitors during the Global Financial Crisis, we explore two distinct aspects of foreign ownership that have been highlighted in the theoretical literature of multinational firms.

The first aspect concerns the production linkages between MNC subsidiaries and parent firms. The existing theoretical literature on the determinants of MNC activities led by Markusen (1984) and Helpman (1984) stresses two main types of MNC subsidiaries: horizontal, which duplicate the production activities of parent firms, and vertical, which share an input-output linkage with parent firms. While horizontal subsidiaries share a substituting relationship with parent firms, the production of vertical subsidiaries complements that of parent firms. In a time of crisis, when a host country experiences a decline in demand, the two types of linkages can lead to sharply different impact. For horizontal MNC subsidiaries, the ability of MNCs to shift production back home will likely result in more volatile performance. For vertical subsidiaries, the intra-firm demand from parent firms will help absorb the negative demand shock in the host country, leading to more resilient responses to the crisis. ${ }^{3}$ This stabilizing role of vertical production linkages should be particularly pronounced

\footnotetext{
${ }^{3}$ By examining the effect of vertical production linkages on establishment performance, our work adds to the debate on the link between vertical integration and the great trade collapse. Bems, Johnson and Yi (2010),
} 
in host countries with large negative demand shocks. We construct a direct measure of production linkages by examining the input-output relationship between the primary products of the subsidiaries and parent firms, i.e., the input-cost share of the subsidiary's primary product category in the parent firm's final-good production. Subsidiaries sharing stronger vertical production linkages with the parents are expected to exhibit more resilience during the crisis. ${ }^{4}$

The second aspect of foreign ownership concerns the financial linkages between MNC subsidiaries and parent firms. An emerging strand of theoretical studies such as Antras, Desai and Foley (2009) highlights MNCs' internal capital markets and investment flows from parents to subsidiaries. In this analysis, we consider how MNCs' internal capital markets lower subsidiaries' dependence on host-country credit conditions, an advantage particularly important when host countries experience credit crunches. To examine this hypothesis, we construct a measure of financial linkages between parents and subsidiaries in each industry using the ratio of investments in subsidiaries relative to total assets. We also consider an alternative approach by constructing a measure of sectoral financial dependence and investigating how the effect of foreign ownership varies with the reliance on financial capital. According to our hypothesis, the effect of foreign ownership on establishment responses to credit crunches should be more pronounced in industries with stronger intra-firm financial linkages and greater financial dependence.

To establish the impact of foreign ownership and linkages on establishment responses to negative economic shocks, we explore the time variation of the data and separately consider the non-crisis (2005-2007) and the crisis (2007-2008) periods. This enable us to use the noncrisis period as a benchmark and compare the effect of foreign ownership during the crisis with its effect in non-crisis years. The comparison helps us identify the effects of foreign ownership that are exclusive to crises periods and the unique role of production and financial linkages in lending MNC subsidiaries greater resilience to negative demand and financial shocks.

Our paper offers new findings on the role of foreign ownership in establishments' resilience to economic crises. We find that MNC subsidiaries responded on average better to the Global Financial Crisis than local controls with similar economic characteristics. Moreover, the advantage of foreign ownership was clearly pronounced during the crisis, but relatively muted during non-crisis years. Compared to local controls, MNC subsidiaries exhibited greater resilience to the crisis but not significantly better performance during normal economic periods.

By investigating why foreign ownership led to divergent performance during the crisis, our analysis also provides one of the first micro evidence on the role of production and financial

investigating the role of global supply chains, argue that increasing vertical specialization contributes to the greater contraction of world trade relative to total output. Bricongne, Fontagnè, et al. (2009) present an alternative argument and show that the extensive presence of supply chains does not automatically explain why world trade overshot the drop in world GDP.

${ }^{4}$ Albeit previously unidentified, this hypothesis is not entirely unexpected. Bernard et al. (2009) have shown that intra-firm trade fell less than unrelated-party trade during the Asian financial crisis. 
linkages in establishment responses to economic crises. We show that establishments sharing stronger vertical production linkages with foreign parent firms exhibited more resilient performance during the crisis, especially in host countries with greater negative demand shocks. Horizontally linked establishments, in contrast, responded to the crisis less positively. Further, the role of vertical production linkages is found significant only during the crisis period. In the non-crisis period, vertical MNC subsidiaries did not perform differently than local matches while horizontal subsidiaries fared slightly better.

In examining the financial linkage hypothesis, we find MNC subsidiaries to exhibit a greater advantage over local counterfactuals in industries with stronger financial linkages between parents and subsidiaries. The effect of financial linkages is especially strong when host-country credit conditions worsened significantly and weak when home-country credit conditions declined. Similar to production linkages, financial linkages are not found to exert a significant effect on establishment performance in the non-crisis period. These results suggest that the linkages between foreign subsidiaries and parent firms play an important role in establishments' resilience to economic crises, but not necessarily in their growth in normal economic time.

Finally, we show that the estimated effect of foreign ownership and linkages is robust to alternative empirical specifications that address issues such as the effect of domestic linkages and unobserved firm heterogeneity. When examining whether the production and financial linkages of domestically owned subsidiaries exerted a similar effect during the crisis, we find that compared to domestically owned subsidiaries, foreign owned subsidiaries exhibited a greater advantage over local counterfactuals in the crisis. Moreover, while financial linkages with domestic parents also played a stabilizing role, the effect of foreign financial linkages was significantly greater and only foreign production linkages had a significant and positive effect on establishments' resilience to the crisis. The results are also robust when we control for unobserved MNC heterogeneity and limit the comparison to subsidiaries owned by the same parent firm. We find subsidiaries with stronger vertical production linkages to the parents to significantly outperform their peers in the same MNC.

Our findings offer important policy implications on the role of FDI during economic crises. Our analysis suggests that FDI exerts a significant but complex effect on economic responses to the crises. The effect is highly contingent on the type and the intensity of linkages established between parent and host countries. Our results indicate that while horizontal MNC activities might be associated with greater economic volatility, vertical production and financial linkages could potentially lessen the impact of the crisis in host countries.

We organize the rest of the paper as follows. We review the existing literature in Section 2. In Section 3, we describe the dataset and the primary variables used in the analysis. The econometric methodology and main empirical evidence are presented in Sections 4 and 5, respectively, and the additional empirical analysis in Section 6. Section 7 concludes. 


\section{Related Literature}

Our paper is closely related to the existing macro and micro literature that evaluates the effects of foreign investments on economic growth and performance. At the macro level, the literature has primarily focused on the role of FDI in country economic growth, and found only weak support for an exogenous positive effect of FDI. Existing evidence shows the effect of FDI to be strongly conditional on local conditions such as human capital and financial sector development (see, for example, Borensztein et al., 1998; Alfaro et al., 2004; Carkovic and Levine, 2005).

The micro-level literature, evaluating the role of foreign ownership in economic performance at establishment level, has found mainly an adverse effect. Most studies find foreign ownership to have a significant negative effect on plant survival and stability, and argue that MNCs' footloose nature makes them more volatile than purely domestic firms. Görg and Strobl (2003), for example, find Irish establishments with foreign ownership to be more likely than indigenous plants to exit the market after controlling for other plant and industry specific characteristics. Gibson and Harris (1996) and Bernard and Sjöholm (2003) reach similar conclusions for New Zealand and Indonesia, respectively. Bernard and Jensen (2007) focus on domestic multinationals in the United State and find them to be more likely than non-multinational firms to shut down home-country plants. ${ }^{5}$

Relatively few analyses have examined the role of foreign ownership in establishment responses to economic crises. Alvarez and Görg (2007), investigating the response of multinational and domestic firms to an economic downturn in Chile, do not find multinationals to react to the economic crisis differently than domestic firms. Desai, Foley and Forbes (2008), evaluating the response of multinational and local firms to sharp currency depreciations, find sales, assets, and investments to increase significantly more for U.S. multinational affiliates than for local firms.

Different from the above studies' focus on regional economic slowdowns and currency depreciations, our analysis draws from the recent Global Financial Crisis. We look to the global coverage and the considerable heterogeneity of the recent crisis to examine the different roles of foreign ownership in establishments' reactions to economic shocks. Furthermore, in contrast to previous studies' focus on evaluating the average effect of foreign ownership, we seek to explore the channels through which foreign ownership can affect establishment performance during economic crises. In doing so, our analysis helps to disentangle some of the ambiguities in previous findings.

Also exploring the recent crisis, Tong and Wei (2009) examine whether the volume and composition of capital flows affected the degree of credit crunch faced by manufacturing firms.

\footnotetext{
${ }^{5}$ Another notable literature on the host-country effects of FDI focuses on the productivity spillovers of multinational firms. See, for example, Haddad and Harrison (1993), Aitken and Harrison (1999), Blomström and Sjöholm (1999), and Javorcik (2004) for studies in this area.
} 
Using data on 3,823 firms in 24 emerging countries, the authors find declines in stock prices to be, on average, more severe for firms intrinsically more dependent on external finance. The volume of capital flows had no significant effect on the severity of the credit crunch, but the composition of capital flows mattered: pre-crisis exposure to non-FDI capital inflows worsened the credit crunch whereas exposure to FDI alleviated liquidity constraints.

In this paper, we investigate both whether and why FDI could lead to better establishment performance during the crisis. We explore the role of production, as well as financial, linkages between MNC subsidiaries and parent firms, and evaluate how the relationships led to differential establishment responses to the negative demand and financial shocks. We also compare the results during the crisis with non-crisis years to examine whether foreign ownership exerts a different effect during economic crises.

\section{Data Description}

\subsection{The Global Financial Crisis and Establishment Performance}

The recent Global Financial Crisis, regarded as the worst financial crisis since the Great Depression of the 1930s, is notable for its speed, severity, and international span. The crisis was triggered by a liquidity shortfall in the U.S. banking system, starting with the collapse of the U.S. subprime industry in 2007 (including the bankruptcy of some of the largest mortgage lenders such as New Century Financial and American Home Mortgage Investment Corporation), and quickly resulted in failures of large financial institutions (such as the fire sale of Bear Stearns in March 2008 and the bankruptcy of Lehman Brothers in September 2008). ${ }^{6}$ The crisis was soon spread to non-financial sectors and economies around the world. Almost all industrial countries and a large number of developing and emerging economies were inflicted in 2008, witnessing substantial declines in total output and employment. Between 2007 and 2008, world GDP fell by 5 percent, unemployment rates rose to 9 percent in industrial nations, and read world exports plunged by 17 percent.

The dramatic shift of the world economy in 2007-2008 constitutes an ideal context for examining micro economic responses to large negative economic shocks. Our analysis draws from this unique episode and exploits its broad coverage as well as considerable heterogeneity, both of which help disentangle the role of foreign ownership in establishment performance from other economic factors.

We employ a new worldwide establishment dataset, WorldBase, that reports the performance of over 12 million establishments in 2005-2008. This dataset provides several distinct advantages over alternative data sources. First, unlike many other sources that lag con-

\footnotetext{
${ }^{6}$ The National Bureau of Economic Research officially determined December 2007 as the end of the economic expansion that began in the U.S. in November 2001 and the beginning of the recession.
} 
siderably in assembling data, WorldBase reports updated 2008 operational information for establishments around the world. ${ }^{7}$ Although the data coverage still does not reflect world population, it enables us to provide one of the first systematic micro-level analysis on the recent crisis.

Second, the dataset, covering establishment activities both before and during the Global Financial Crisis, enables us to compare the role of foreign ownership during the crisis with the non-crisis years. Using the non-crisis period as a counterfactual helps us identify the effect of foreign ownership, including production and financial linkages, on establishment responses to adverse economic shocks.

Third, central to our analysis, the unit of observation in WorldBase is establishment (a single physical location at which production operations or services are performed) instead of firm. Establishments have their own addresses, business names, and managers, but might be partly or wholly owned by other firms. The database supports the linking of establishments to firms using information on domestic and global parents and the DUNS identification. ${ }^{8}$

Fourth, the dataset covers a larger number of countries than alternative data sources, enabling a comprehensive analysis of the crisis for both developed and developing nations and for countries at the epicenter as well as on the periphery of the crisis. It also allows us to investigate how the role of foreign ownership varies across countries depending on the incidences of the crisis.

WorldBase is complied by Dun \& Bradstreet (D\&B) and covers public and private enterprises in over 100 countries and territories. Dun \& Bradstreet has been the leading source of commercial credit and marketing information since 1845, and presently operates in more than a dozen countries and territories either directly or through affiliates, agents, and associated business partners. D\&B compiles data from a wide range of sources including public registries, partner firms, telephone directory records, and websites, and verifies all information centrally via a variety of manual and automated checks. Early uses of the D\&B data include Caves' (1975) size and diversification pattern comparisons between Canadian and U.S. domestic plants and subsidiaries of U.S. multinationals in Canada, and Lipsey's (1978) comparisons of the $\mathrm{D} \& \mathrm{~B}$ data with existing sources with regard to the reliability of U.S. data. Recent research that has used the D\&B data includes Harrison, Love, and McMillian's (2004) analysis of capital flows, Black and Strahan's (2002) study of entrepreneurial activity in the United States, Acemoglu, Johnson, and Mitton's (2009) cross-country study of concentration and vertical integration, and Alfaro and Charlton's (2009) analysis of vertical and horizontal

\footnotetext{
${ }^{7}$ For example, the latest UNIDO INDSTAT 2009 Database, an authority industry-level data source, reports industrial data only up to 2007. The OECD STAN Database, another widely used industry-level dataset, currently provides 2008 data for only 13 OECD countries.

${ }^{8}$ To identify businesses numerically for data-processing purposes, D\&B introduced in 1963 the Data Universal Numbering System (the D-U-N-S Number). The system supports the linking of plants and firms across countries and tracking of plant histories including name changes.
} 
activities of multinationals.

We impose a number of requirements in cleaning the data. First, we drop records that lack primary industry classification and starting year information. Second, we restrict the data to establishments that report sales information for all years. Moreover, we include only establishments with positive sales and employment in 2005. Requiring positive employment helps to exclude establishments registered exclusively for tax purposes as well as self-employment businesses. These types of establishments constitute a significant share of businesses in countries such as the United States. Finally, we drop agricultural and mining industries as well as countries with fewer than 100 observations. These criteria result in a final sample of approximately 12 million establishments in 53 countries.

We use four categories of information for each establishment: (i) industry information including the 4-digit SIC code of the primary industry in which each establishment operates and, for most countries, the SIC codes of as many as five secondary industries, listed in descending order of importance; (ii) ownership information including the establishments' domestic and global parents, status (joint-venture, corporation, partnership), and position in the hierarchy (branch, division, headquarters); (iii) location information; (iv) operational information including sales, employment, and export status.

Establishment performance is measured in this paper by the annual percentage change of sales. An establishment is considered foreign owned if its parent firm is based in a different country. There are 43,513 foreign owned subsidiaries in the final sample.

\subsection{Production Linkages}

To measure the production linkages between subsidiaries and foreign parent firms, we examine the input-output relationship between each subsidiary's primary product category and the parent firm's final goods.

First, we follow Acemoglu et al. (2009) and Alfaro and Charlton (2009) in considering two main types of MNC subsidiaries: horizontal and vertical. Horizontal subsidiaries refer to subsidiaries that duplicate parent firms' final-good production. We identify these subsidiaries by comparing their primary product category with the final product categories of their parent firms, all reported at SIC 4-digit level. If the subsidiary's primary product category is listed as one of the parent firm's final products, the subsidiary is considered as horizontal. ${ }^{9}$ The manufacturing industries in which we observe the largest number of horizontal subsidiaries include, for example, motor vehicle parts and accessories, plastics products n.e.c., electronic components n.e.c., pharmaceutical preparations, and chemicals and chemical preparations.

Vertical subsidiaries refer to subsidiaries that share a vertical production linkage with

\footnotetext{
${ }^{9}$ We also separately considered subsidiaries that produce parent firms' core final product and those that produce secondary final products and did not find the two types of horizontal subsidiaries to have different performance.
} 
parent firms. Specifically, a subsidiary is considered vertical if the direct requirement of the subsidiary's primary product category in the parent firm's final-good production, measured by the input cost share, exceeds a threshold value $0.1 .^{10}$

Note that there are also subsidiaries that are neither horizontal nor vertically linked to their parent firms. ${ }^{11}$ The production activities of these subsidiaries can be viewed as independent of the production activities of their parents, and are as a result not expected to benefit from vertical production linkages like vertical subsidiaries during economic crises.

Alternative to dividing subsidiaries to different groups, we also directly take into account the strength of the production linkages, i.e., the input-cost share of the subsidiary's primary product category in the parent firm's final-good production. Subsidiaries whose primary products account for a greater share of the parent firms' total input costs are considered to exhibit a stronger vertical production linkage with the parent firms.

As in Acemoglu et al. (2009) and Alfaro and Charlton (2009), the input-output relationships between product categories are taken from the U.S. 2002 Benchmark Input-Output Accounts published by the Bureau of Economic Analysis. Constructing the production linkage measure using the U.S. input-output accounts data is motivated by three considerations. First, compared to firm-level input-output information which is typically unavailable, industry-level input-output relationships reflect standardized production technologies and are relatively stable over time, limiting the potential for the production linkage measure to endogenously respond to idiosyncratic shocks. Second, using the U.S. as the reference country further mitigates the possibility of endogenous production linkage measures. Third, the U.S. inputoutput accounts are more disaggregated than most other countries, enabling us to dissect vertical production linkages between detailed product categories.

The manufacturing industry pairs with the strongest vertical production linkages include, for example, (i) motor vehicles and passenger car bodies, and motor vehicle parts and accessories, (ii) plastics materials, synthetic resins, and nonvulcanizable elastomers, and plastics products, (iii) air-conditioning and warm air heating equipment and commercial and industrial refrigeration equipment, and motor vehicles and passenger car bodies.

\subsection{Financial Linkages}

The financial linkages between parent firms and subsidiaries are also typically not observed for most firms. We thus construct a variable to represent the degree of intra-firm financial linkages in each industry. We assume that because of heterogeneity in intrinsic industry characteristics such as headquarter intensity and capital intensity, industries incur different benefits and costs from financial integration and thus have different incentives to invest in subsidiaries. This assumption is consistent with the findings of a growing literature led by Antras (2003) and

\footnotetext{
${ }^{10}$ We also considered different threshold values and found the results relatively similar.

${ }^{11}$ This type of subsidiaries accounts for 6 percent of foreign owned subsidiaries.
} 
Antras and Helpman (2004), who show that industries with higher headquarter intensity and capital intensity tend to have greater incentives to engage in integration and subsidiary investment.

To measure the degree of intra-firm financial linkages in each industry, we use the ratio of investments in subsidiaries relative to total assets for the median firm of each industry. This ratio captures the extent of financial integration by the industry of parent firms. Given that the information required to compute the variable is not systematically available for private firms around the world, the variable is computed based on a dataset of publicly listed companies obtained from the Global COMPUSTAT. The measure is averaged for 2000-2004 to smooth out temporary fluctuations.

While identification of our analysis does not require industries to have exactly the same financial linkage levels over time and across countries, it does rely on the ranking of industries to be relatively stable. Otherwise, the proxy could potentially bias us against finding any relationship between financial linkages and establishment responses to economic crises. For this reason, we perform two checks on the variable. First, we construct the measure using data from different time periods and find the ranking of industries to be relatively stable over time. This observation suggests that industries' ranking in the degree of intra-firm financial linkages is mainly dependent on characteristics innate to each industry and thus unlikely to change structurally in response to short-term idiosyncratic shocks. Second, we compute the variable for each major MNC parent country and find high rank correlations across countries. For our empirical analysis, we do not use country-specific measures to mitigate potential endogeneity even though in doing so our estimates could be potentially biased downward.

According to our measure, industries that exhibit the strongest financial linkages between parents and subsidiaries include cut stone and stone products, newspapers: publishing or publishing and printing, fats and oils, ordance and accessories except vehicles and guided missiles, grain mill products, broadwoven fabric mills, manmade fiber and silk, paperboard mills, and petroleum refining. ${ }^{12}$

We also consider an alternative approach to examine the financial linkage hypothesis. We follow Rajan and Zingales (1998) and Braun and Larrain (2005) in constructing a measure of financial dependence for each industry. The expectation is that if financial linkages play a significant role in helping establishments attain greater resilience to credit crunch, the role should be particularly pronounced in industries with greater financial dependence.

The financial dependence variable is measured using the share of capital expenditure not

\footnotetext{
${ }^{12}$ As a robustness check, we also computed the financial linkage variable using the average share of affiliate assets financed by parent firms in each industry based on the U.S. BEA Direct Investment Abroad Benchmark Data. The results were largely similar. This measure has been considered in Antras, Foley and Desai (2009). Their analysis shows that host-country characteristics can exert a significant effect on the level of financial linkages within MNCs. But to the extent that the effect of country characteristics applies symmetrically across industries as shown in their paper, the ranking of industries is likely to be relatively similar across countries.
} 
financed with cash flows from operations for the median firm in each industry, and captures establishments' dependence on other sources of capital supply such as external loans and intrafirm financing. Similar to the financial linkage variable, the financial dependence measure is computed using the 2000-2004 publicly listed company data from Global COMPUSTAT, with the ranking of industries found relatively stable over time and highly correlated across major countries. Rajan and Zingales (1998) and Braun and Larrain (2005) argue that the measure of financial dependence captures a large technological component that is innate to a sector and is therefore a good proxy for ranking industries in all countries. Industries with the greatest financial dependence according to this classification include, for example, electric machinery, textiles, transport equipment, plastic products, and primary metal.

\subsection{Other Economic Characteristics}

A variety of other establishment-level economic characteristics including sales, labor productivity, age, multi-product status, and exporter status, all lagged by two years, are also taken into account. We use lagged sales to control for establishment size, and labor productivity to proxy for efficiency. We also considered alternative measures such as employment size and market share and found similar results. In addition, we take into account each establishment's age and multi-product status. The latter variable is an indicator variable that identifies establishments producing more than one product, and helps control for the effect of product diversification. Finally, we use an indicator variable to separate exporting establishments from establishments that sell only domestically. This variable helps capture the role of previous export participation.

\section{Econometric Strategy}

The primary goal of our empirical analysis is to evaluate, first, the net effect of foreign ownership on establishment performance during the crisis and, second, conditional on foreign ownership how production and financial linkages led to the differential responses of MNC subsidiaries.

An empirical issue that can arise when evaluating the net effect of foreign ownership is the potential endogeneity of foreign ownership status. For example, one can argue that foreign MNCs may have performed better during the crisis because they acquired more productive local establishments or due to unobserved characteristics. If this were the case, the estimated effect of foreign ownership could suffer from selection bias. ${ }^{13}$

\footnotetext{
${ }^{13}$ The estimated effect of production and financial linkages conditional on foreign ownership is less likely to be subject to the above concern because the identification there is primarily drawn from variations across foreign owned subsidiaries and how they relate to cross-industry variations in the degree of production and financial linkages. As described in Sections 3.2-3.3, both linkage measures reflect characteristics intrinsic to
} 
To mitigate the potential endogeneity of foreign ownership status, we employ a matching technique that creates the missing counterfactual of each foreign owned subsidiary's performance had the establishment not been owned by foreign MNCs. This is done by matching each foreign owned subsidiary with a local establishment based on economic characteristics, such as lagged sales, labor productivity, age and previous exporter status. Each matched pair thus shared similar economic attributes prior to the evaluation period, except the status of foreign ownership. We then evaluate the effect of foreign ownership by comparing the performance of matched establishments.

Formally, the effect of foreign ownership in a given period can be expressed as follows:

$$
\beta \equiv E\left(Y_{1} \mid \text { foreign ownership }=1\right)-E\left(Y_{0} \mid \text { foreign ownership }=1\right)
$$

where $\beta$ denotes the estimated effect of foreign ownership, $Y$ represents the outcome of interest, i.e., annual percentage change of sales, the subscript of $Y$ describes the (potentially hypothetical) circumstances under which the outcome is evaluated with 1 denoting the case with foreign ownership and 0 denoting the case without foreign ownership, and foreign ownership $=1$ refers to the group of establishments owned by foreign MNCs (i.e., the treatment group). The above equation represents the difference in performance between a foreign owned subsidiary (the first right-hand-side term) and the same establishment had it not been foreign owned (the second term). The latter, however, is an unobserved counterfactual.

The matching method is a strategy of constructing the unobserved counterfactual by identifying a match with similar economic characteristics for each foreign owned subsidiary. The underlying assumption is that the matched pairs, conditioning on the observed characteristics $X$, would perform similarly under the same circumstances. Hence, the above equation can be rewritten as:

$$
\begin{aligned}
& \beta=E\left(Y_{1} \mid \text { foreign ownership }=1, X\right)-E\left(Y_{0} \mid \text { foreign ownership }=0, X\right) \\
& -\left[E\left(Y_{0} \mid \text { foreign ownership }=1, X\right)-E\left(Y_{0} \mid \text { foreign ownership }=0, X\right)\right] .
\end{aligned}
$$

The first difference on the right hand side of the above equation represents the observed difference in performance between foreign owned and local establishments. The second difference represents the selection bias, that is, the difference in performance between foreign owned subsidiaries, under the hypothetical circumstances that they had not been foreign owned, and local establishments. Our goal is to minimize the selection bias through the matching process and estimate the effect of foreign ownership. Given the large dimension of observable char-

each industry and are thus unlikely to depend on unobserved establishment or country factors. As a robustness check, we also did not find a systematic relationship between pre-crisis establishment and parent characteristics, such as size, labor productivity and age, and the observed linkages. 
acteristics, we employ propensity score matching. ${ }^{14}$ We perform the procedure for non-crisis and crisis periods separately to examine whether the effect of foreign ownership varies during the crisis.

We proceed in two stages. In the first stage, we estimate a probit model of establishment foreign ownership status, with lagged observable establishment characteristics as explanatory variables. To increase the precision of the matching, the estimation (and the subsequent matching) is performed for each country and sector. Consistent with the literature, we find a significant and positive relationship between foreign ownership status and establishment size and labor productivity for most countries and sectors. ${ }^{15}$ The predicted probability of being foreign owned (or the propensity score), denoted by $P(X)=\operatorname{Pr}($ foreign ownership $=1 \mid X)$, forms the basis of the matching procedure.

In the second stage, we adopt one-to-one nearest neighbor matching and identify a local establishment $l$ for each foreign owned subsidiary $i$ such that

$$
l(i)=\underset{j \mid \text { foreign ownership }}{\arg =0}\left|P_{j}(X)-P_{i}(X)\right|,
$$

that is, the difference in the predicted probability of being foreign owned in minimized. We impose an additional requirement that the match must come from the same country and sector. ${ }^{16}$ To assess how well the propensity score matching performs in our analysis, we undertake tests of the balancing property and find no statistically significant differences between the treated and the control group in terms of lagged economic characteristics. Moreover, our matched pairs of establishments are, on average, 0.02 percentage point apart in terms of the propensity score. These observations give us confidence that our matching procedure has grouped together relatively homogeneous establishments.

The average treatment effect of foreign ownership can then be inferred from the average performance difference of matched pairs, that is,

$$
\beta=E\left(Y_{i}\right)-E\left(Y_{l(i)}\right)
$$

To examine how production and financial linkages led to the differential performance of

\footnotetext{
${ }^{14}$ This technique is proposed in the seminal work of Rosenbaum and Rubin (1983) and has become increasingly popular in recent empirical research along with other matching estimators developed to estimate average treatment effects.

${ }^{15}$ Given the first-stage estimation is performed for each country and sector, the estimation results are suppressed in the paper because of space consideration and available upon request.

${ }^{16}$ In the matching procedure, we exclude observations outside the common support. The common support is bound by the lowest propensity score of a treatment observation and the highest propensity score of a control observation.
} 
foreign owned subsidiaries, we employ the following baseline empirical specification:

$$
Y_{i}-Y_{l(i)}=\alpha+\gamma_{1} \text { Prod Linkages }_{i}+\gamma_{2} \text { Financial Linkages }_{i}+\varepsilon_{i}
$$

where $Y_{i}-Y_{l(i)}$ denotes the performance difference between foreign owned subsidiary $i$ and its

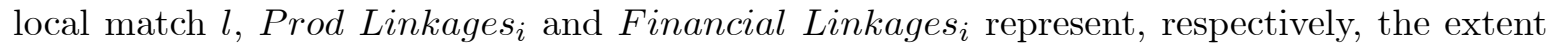
of sectoral production and financial linkages between subsidiary $i$ and its parent firms, $\gamma_{1}$ and $\gamma_{2}$ represent, respectively, the effect of production and financial linkages on foreign owned subsidiaries' performance relative to local matches', and $\varepsilon_{i}$ denotes the residuals. Given that the dependent variable is constructed from the matching analysis, the residuals are bootstrapped with industry clustering.

\section{Main Empirical Evidence}

In this section, we first present the estimated average effect of foreign ownership in crisis and non-crisis periods, and then examine the role of production and financial linkages in explaining the effect of foreign ownership.

\subsection{The Average Effect of Foreign Ownership}

Table 1 reports the average treatment effect of foreign ownership, $E\left(Y_{i}\right)-E\left(Y_{l(i)}\right)$, for crisis and non-crisis years, respectively. The results indicate that foreign owned subsidiaries exhibited on average higher sales growth rates than their local matches in 2007-2008. The performance difference between the matched pairs of establishments is both statistically and economically significant, and estimated around 3 percentage points. In contrast to the crisis period, the average treatment effect of foreign ownership is significantly moderate in non-crisis years. Foreign owned subsidiaries displayed merely 0.2 percentage point higher sales growth rates than local matches in 2005-2007. The difference between crisis and non-crisis years in the estimated treatment effect of foreign ownership is statistically significant as indicated by the last column of Table 1.

[Table 1 about here]

These results suggest that foreign ownership exerted a positive effect on establishments' resilience to the Global Financial Crisis, but a very limited effect on establishment performance in non-crisis years. In the following sub-sections, we investigate the different mechanisms that can lead to performance difference between foreign owned and domestic establishments, especially during economic crises. 


\subsection{The Role of Production Linkages}

First, we evaluate the role of production linkages. Table 2 breaks down the estimated effect of foreign ownership by the type of production linkages, including horizontal subsidiaries, vertical subsidiaries and neither category. The estimates suggest that foreign MNC subsidiaries with vertical production linkages to parent firms significantly outperformed their local matches during the crisis, exhibiting 23 percentage points higher growth rates. This performance difference is observed only during the crisis period. Foreign MNC subsidiaries and local counterfactuals showed similar percentage changes of sales in 2005-2007, despite the former's vertical production linkages. In contrast, MNC subsidiaries with horizontal production linkages to their parents fared slightly better than their local matches during non-crisis years, while the two groups did not differ significantly in the crisis. But the performance gap between horizontal subsidiaries and local counterfactuals is not significantly different between crisis and non-crisis periods. Finally, subsidiaries with neither type of production linkages did not perform differently than local matches in both crisis and non-crisis periods.

[Table 2 about here]

In Table 3, we systematically assess the role of vertical production linkages by regressing MNC subsidiaries' performance difference from local matches, i.e., $Y_{i}-Y_{l(i)}$, on the strength of their input-output relationship with parent firms, i.e., Prod Linkages L $_{i}$ measured by the input-cost share of the subsidiary's primary product category in the parent firm's final-good production. The results suggest that subsidiaries sharing a stronger vertical production linkage with their parents tended to exhibit a greater advantage over local counterfactuals during the crisis. According to column (3), a one-percentage-point increase in the input-output linkage is associated with 1.06 percentage points higher growth rates. This effect is found only during the crisis period, however. In contrast to the crisis period, we do not observe a significant relationship between the strength of input-output linkages and MNC subsidiaries' performance in non-crisis years. The above result suggests that vertical production linkages lead to greater resilience to negative economic shocks, but not necessarily superior performance in the absence of negative shocks. In columns (2) and (4), we control for the effect of country characteristics on the relative performance of MNC subsidiaries by limiting the analysis to within-country variations. ${ }^{17}$ The findings are largely similar.

[Table 3 about here]

The vertical production linkage between foreign owned subsidiaries and parent firms also determines that the former should exhibit a greater advantage over local competitors when

\footnotetext{
${ }^{17}$ Recall that country-industry specific factors that uniformly affect the performance of foreign owned and domestic establishments have been controlled for in the matching analysis by the pairing of foreign owned subsidiaries and local establishments from the same country and industry.
} 
host countries experience a greater incidence of the crisis, in particular, a larger negative demand shock. MNC subsidiaries sharing an input-output relationship with their parent firms tend to engage in more intra-firm trade, thereby less dependent on host-country domestic demand conditions. When the demand in host countries contracts, the intra-firm demand will help absorb part of the shock, leaving the subsidiaries less affected by the crisis. This advantage of vertical MNC subsidiaries is particularly important when the demand shocks in the host countries are relatively large.

The above mechanism conversely implies that the advantage of vertically linked MNC subsidiaries should be negatively associated with the incidence of the crisis in MNCs' home countries. A better demand condition at home will enhance the advantage of vertical subsidiaries abroad, while a worse incidence of the crisis in home markets adversely affects those MNC subsidiaries' performance overseas.

We examine the above hypotheses in Table 4. The incidence of the crisis, in particular, the degree of the demand shock is proxied here by the average percentage decrease of sales in each host country and industry. The measure was constructed using either all establishments in the entire WorldBase dataset or the subset that excludes MNC subsidiaries and their local matches. The results were similar. ${ }^{18}$ The estimates obtained with the latter measure are reported in Table 4.

\section{[Table 4 about here]}

We find that, first, the effect of vertical production linkages on MNC subsidiaries' relative performance increases in the incidence of the crisis in host countries. Vertical MNC subsidiaries exhibited a greater advantage over local counterfactuals in countries with larger negative demand shocks. In contrast, the effect of vertical production linkages is not significantly associated with the incidence of the crisis in MNCs' home countries.

\subsection{The Role of Financial Linkages}

Now we consider the role of financial linkages in explaining MNC subsidiaries' different performance relative to local competitors. Unlike local establishments, MNC subsidiaries have an additional source of capital supply, i.e., internal capital flow from parent firms. This internal capital support from home enables MNC subsidiaries to achieve greater resilience to host-country financial shocks than local establishments.

Table 5 reports the estimated effect of parent-subsidiary financial linkages, i.e., Financial Linkages $_{i}$, on MNC subsidiaries' performance difference from local counterfactuals $Y_{i}-Y_{l(i)}$. We find that in industries with stronger financial linkages between parents and subsidiaries,

\footnotetext{
${ }^{18}$ We also used countries' GDP growth rates and import growth rates as alternative proxies and found similar results.
} 
MNC subsidiaries fared better than their local matches during the crisis. A one-percentagepoint increase in the ratio of investments in subsidiaries is associated with 4.6 percentage points higher growth rates. This result does not change when we control for the effect of vertical production linkages and estimate the full equation (5). Like production linkages, the effect of financial linkages is observed only during the crisis period. The degree of financial linkages does not appear to affect establishment performance during non-crisis years. This sharp contrast of results suggests that the linkages between foreign subsidiaries and parent firms play an important role in helping MNC subsidiaries better respond to negative economic shocks, but not necessarily in achieving superior growth in the absence of economic shocks.

[Table 5 about here]

Another way to investigate the role of financial linkage is to examine whether the effect of foreign ownership increases in the level of financial dependence. In Table 6, we find a positive relationship between MNC subsidiaries' performance difference from local matches and industries' financial dependence level. A one-percentage-point increase in the level of financial dependence is associated with 0.27 percentage point higher growth rates in 2007-2008. The relationship between financial dependence and effect of foreign ownership is significantly weaker in the non-crisis period. A one-percentage-point increase in the level of financial dependence is associated with 0.02 percentage point higher growth rates. Again, vertical production linkages did not play a significant role in non-crisis years.

[Table 6 about here]

The role of financial linkages in establishment responses to the crisis is also expected to increase in the incidence of the crisis in host countries' financial markets. The internal capital supply from parent firms overseas should be particularly valuable when the host-country credit conditions worsen. MNC subsidiaries in industries with stronger intra-firm financial linkages are thus expected to exhibit a greater advantage over local competitors when host countries experience greater negative financial shocks.

Conversely, the role of intra-firm financial linkages in helping MNC subsidiaries attain greater resilience should depend on the incidence of the crisis in MNCs' home-country financial markets. A worse credit condition at home will weaken the capital supply from parent firms, adversely affecting MNCs' performance overseas.

Following Rose and Spiegel (2009a), the incidence of the crisis in financial markets is measured here by countries' drop in credit ratings during 2007-2008. Countries that experienced a bigger drop in credit ratings are considered to have a greater incidence of the crisis in financial markets. As in Rose and Spiegel (2009a), we adopt country credit ratings from the Institutional Investor magazine, which ranks 177 countries on a scale from 0 to 100 with 100 
representing the least likelihood of default (as of March 2009, Switzerland was the most highly ranked country with a score of 94.0, while Zimbabwe rated at the rear with a score of 4.6). According to this rating, countries such as New Zealand, Ireland, Greece and Singapore were among the group with the largest decline in credit conditions while countries such as Brazil, Peru and Ecuador showed a lesser incidence of the financial crisis.

[Table 7 about here]

Table 7 reports the results. We find that the effect of financial linkages on establishment resilience to the crisis increases in host countries' incidence of financial crisis. MNC subsidiaries exhibited a greater advantage over local competitors in host countries that experienced a larger decline in credit ratings. In contrast, the positive effect of financial linkages is smaller when MNC home countries experienced large negative financial shocks. MNC subsidiaries performed less satisfactorily when their home countries' credit conditions worsened.

\section{Additional Analysis}

\subsection{Foreign v.s. Domestic Linkages}

So far our analysis has emphasized on the effect of cross-country production and financial linkages between foreign owned subsidiaries and their foreign parents. But would the same effect exist for the production and financial linkages between domestically owned subsidiaries and their domestic parents?

Similar to foreign parent firms, domestic parents can engage in intra-firm trade with subsidiaries and provide the latter internal capital supply. These linkages can help subsidiaries sustain resilience to local demand and financial shocks. However, when the shocks occur at the country level, the effect of these linkages will be much weaker than the linkages of foreign owned subsidiaries because the former are located within the same country and exposed to the same shocks. The linkages between subsidiaries and foreign parents, in contrast, can provide more stability in this case, because the parent firms are not directly affected by the host-country crisis.

To compare the effect of foreign and domestic linkages, we expand our final sample to include establishments owned by domestic parents. Similar to Section 4, we perform a matching analysis to match each domestically owned subsidiary with a local stand-alone establishment from the same country and industry based on economic characteristics. The matched pairs share similar attributes such as lagged size, lagged labor productivity, age, and previous exporter status, except the status of domestic parent ownership. We then compare the performance of the matched pairs to establish the effect of having domestic parents. As in the 
analysis of foreign owned subsidiaries, we identify the extent of production and financial linkages between the establishments and their domestic parents and investigate how they affect subsidiaries' performance during the crisis.

Table 8 reports the results. First, we find in column (1) that compared to domestically owned subsidiaries, foreign owned subsidiaries exhibited a greater advantage over local counterfactuals. The performance gap between the latter two groups is 18 percentage points higher than the gap between domestically owned subsidiaries and their local stand-alone matches. In column (2), we allow the effect of production and financial linkages to vary between domestic and parent firms. The results show that while financial linkages with domestic parents also played a stabilizing role during the crisis, the effect of foreign financial linkages was significantly greater. Furthermore, only foreign production linkages are found to exert a significant and positive effect on establishments' resilience to the crisis; domestic production linkages did not significantly affect establishment performance.

[Table 8 about here]

\subsection{Network Effect}

In addition to production and financial linkages with foreign parent firms, MNC subsidiaries exhibit another distinct feature compared to domestic establishments. That is, most multinationals today operate a multilateral network. Having a larger multilateral network enables multinationals to diversify both product and financial markets. In this subsection, we take into account this aspect of multinational firms and examine how a larger multinational network can potentially amplify the effect of production and financial linkages.

To do so, we first construct two variables to represent the number of countries in the MNC networks. First, we control for the total number of countries outside the subsidiary in which MNCs operate. Operation in a larger number of countries implies greater product market diversification and potentially greater intra-firm demand, lending subsidiaries stronger resilience to negative host-country demand shocks. Furthermore, a larger network outside the subsidiary country means that multinationals can offer subsidiaries internal capital flows from more sources, mitigating subsidiaries' vulnerabilities to host-country financial shocks.

However, within the aggregate network, the subset that performs identical production activities as the subsidiary of interest should be considered separately. A larger network of duplicate production means that multinationals can more easily substitute production across countries. In a time of negative demand and financial shocks, multinationals are more likely to react to the shocks by shifting production to the rest of the network, resulting in greater

volatility. Our second variable hence measures the number of countries in which MNCs duplicate the subsidiary's production, also referred to as the subsidiary's horizontal network. 
Alternative to the simple country counts, we can also take into account the relative size of the MNC network outside the subsidiary. We compute the share of multinationals' revenue received from third and parent countries relative to the share of revenue from the subsidiary of interest, in either all product categories or just the product category of the subsidiary. A larger share of total revenue from third and parent countries offers subsidiaries stronger intrafirm demand and capital supply, enhancing subsidiaries' resilience to host-country demand and financial shocks. But a relatively larger horizontal network that may substitute the subsidiary's production can lead to footloose behavior and more volatile performance.

Table 9 reports the results. We find that a greater aggregate network outside the subsidiary is associated with better subsidiary performance compared to local matches. This result lends support to the positive role of overall market diversification in times of economic volatility. In contrast, the size of the subsidiary's horizontal network did not play a significant role, suggesting that the opposing effects of this type of network lead to an ambiguous net effect. Comparing the crisis with non-crisis years, we again find that, similar to production and financial linkages, the stabilizing role of networks is pronounced only during the crisis.

[Table 9 about here]

\subsection{Unobserved MNC heterogeneity}

The matching technique adopted in the paper helps us identify the effect of foreign ownership by limiting the comparison to establishments with similar economic characteristics. There could, however, remain unobserved heterogeneity across MNCs that is correlated with the degree of production and financial linkages.

We take two steps to address this issue. First, we control for potential correlations of residuals between establishments owned by the same parent firm, as well as between establishments in the same industry. Cameron, Gelbach and Miller's (2006) multi-way clustering method is employed for this purpose. As shown in Table 10, the standard errors remain similar. Both production and financial linkage measures continue to play a significant role in explaining the performance difference between MNC subsidiaries and their local matches.

[Table 10 about here]

Second, we control for all firm-level characteristics by including a parent firm fixed effect and limiting the comparison to establishments owned by the same parent firm. Multinationals with only one foreign subsidiary are hence dropped from the sample. In doing so, we establish the role of production linkages by comparing the performance of subsidiaries that belong to the same multinational but with different degrees of input-output linkages. The effect of financial linkages cannot be estimated in this specification because our measure of financial linkages does not vary within each parent firm. 
[Table 11 about here]

Table 11 reports the results. We continue to find vertical production linkages to exert a significant effect on MNC subsidiaries' performance during the crisis. A one-percentage-point increase in the input-output relationship is associated with 1.28 percentage points higher growth rates, exceeding the estimated effect in Table 3. Again, the production linkages do not appear to systematically affect establishment performance in non-crisis years.

\section{Conclusion}

We investigate in this paper the role of foreign ownership in establishment performance during the recent Global Financial Crisis. Using a worldwide establishment panel dataset, we examine whether foreign ownership led to different resilience to the crisis between establishments with similar economic attributes and how the role varies from non-crisis periods. Moreover, we examine how, conditional on foreign ownership, production and financial linkages explain the differential responses of MNC subsidiaries.

We find that MNC subsidiaries responded on average better to the recent crisis than local controls with similar economic characteristics. The advantage of foreign ownership was clearly pronounced during the crisis, while relatively muted in non-crisis years. Production and financial linkages played critical roles in explaining the differential responses of MNC subsidiaries. Establishments sharing stronger vertical production linkages with foreign parent firms exhibited more resilient performance during the crisis, especially in host countries with a greater incidence of the crisis. Horizontally linked establishments, in contrast, responded to the crisis less positively. The same pattern is not observed in non-crisis years. Vertical MNC subsidiaries did not perform differently than their local matches in the non-crisis period, while horizontal subsidiaries fared slightly better. Financial linkages similarly played an important role during the crisis. MNC subsidiaries operating in industries with greater intra-firm financial linkages exhibited a greater advantage over local counterfactuals. Similar to production linkages, the role of financial linkages was significant only during the crisis period, especially in host countries with significantly worsened credit conditions.

Our results suggest that foreign ownership plays a significant and complex role in micro economic responses to economic crises. It is important to disentangle the underlying channels. Foreign ownership can either exacerbate or alleviate the adverse impact of the crises depending on the nature and the intensity of the linkages between MNC subsidiaries and parent firms. While multinationals' footloose behavior might lead to greater volatility in horizontally linked subsidiaries, vertical production and financial linkages could potentially alleviate the impact of the crisis in host countries. These findings are central to academic and policy debates centered on the role of foreign direct investment in economic growth and volatility, and have 
critical implications for policy making that influence the flow of foreign investments.

A promising avenue of future research comprises, for example, analysis on the role of multinational linkages in cross-country economic interdependence, in particular, how the linkages may serve as international transmission mechanisms in a time of economic crises. Our results show that the performance of MNC subsidiaries is conditional on the incidence of the financial crisis in parent countries. Further research on how multinationals' intra-firm production and financial linkages could transmit shocks from parent to host countries and vice versa and between different host nations could offer useful academic and policy insights. 


\section{References}

[1] Acemoglu, Daron, Simon Johnson, and Todd Mitton (2009) Determinants of Vertical Integration: Financial Development and Contracting Costs. Journal of Finance 63, 12511290.

[2] Aitken, Brian J., and Ann E. Harrison (1999) Do Domestic Firms Benefit from Foreign Direct Investment? Evidence from Venezuela. American Economic Review 89 (3), 605618.

[3] Alfaro, Laura and Andrew Charlton (2009) Intra-Industry Foreign Direct Investment. American Economic Review 99 (5), 2096-2119.

[4] Alfaro, Laura, Areendam Chanda, Sebnem Kalemli-Ozcan, and Selin Sayek (2004) FDI and Economic Growth: the Role of Local Financial Markets. Journal of International Economics 64 (1), 89-112.

[5] Alvarez, Roberto and Holger Görg (2007) Multinationals as Stabilizers? Economic Crisis and Plant Employment Growth. IZA Discussion Paper 2692.

[6] Antras, Pol (2003) Firms, Contracts, and Trade Structure. Quarterly Journal of Economics 118 (4), 1375-1418.

[7] Antras, Pol, Mihir Desai, and Fritz Foley (2009) Multinational Firms, FDI Flows and Imperfect Capital Markets. Quarterly Journal of Economics 124 (3), 1171-1219.

[8] Antras, Pol, and Elhanan Helpman. Global Sourcing. Journal of Political Economy 112 (3), 552-580.

[9] Baldwin, Richard and Simon Evenett (2009) The Collapse of Global Trade, Murky Protectionism, and the Crisis: Recommendations for the G20. A VoxEU.org Publication.

[10] Bems Rudolfs, Robert Johnson, and Kei-Mu Yi (2010) Demand Spillovers and the Collapse of Trade in the Global Recession. Mimeo.

[11] Bernard, Andrew and Bradford Jensen (2007) Firm Structure, Multinationals and Manufacturing Plant Deaths. Review of Economics and Statistics 89 (2), 193-204.

[12] Bernard, Andrew, Bradford Jensen, Stephen Redding, and Peter Schott (2009) The Margins of US Trade. American Economic Review Papers and Proceedings 99 (2), 487-493.

[13] Bernard, Andrew and Fredrik Sjöholm (2003) Foreign Owners and Plant Survival. NBER Working Paper No. 10039. 
[14] Black, S. E., and P. E. Strahan (2002) Entrepreneurship and Bank Credit Availability. Journal of Finance 57, 2807-2833.

[15] Blomström, Magnus and Fredrik Sjöholm (1999) Technology Transfer and Spillovers: Does Local Participation with Multinationals Matter? European Economic Review 43, 915-923.

[16] Borensztein, E., J. De Gregorio, and J-W. Lee (1998) How Does Foreign Direct Investment Affect Economic Growth? Journal of International Economics 45, 115-135.

[17] Braun, Matias, and Borja Larraini (2005) Finance and the Business Cycle: International, Inter-Industry Evidence. Journal of Finance 60 (3), 1097-1128.

[18] Bricongne, Jean-Charles, Lionel Fontagné, Guillaume Gaulier, Daria Taglioni and Vincent Vicard (2009). Firms and the Global crisis: French Exports in the Turmoil. Mimeo.

[19] Carkovic, M. and R. Levine (2005) Does Foreign Direct Investment Accelerate Economic Growth? In T. Moran, E. Grahan, and M. Blomström (eds.), Does Foreign Direct Investment Promote Development? Washington D.C.: Institute for International Economics.

[20] Caves, Richard E. (1975) Diversification, Foreign Investment and Scale in North American Manufacturing Industries. Ottawa: Economic Council of Canada.

[21] Chor, Davin and Kalina Manova (2009) Off the Cliff and Back: Credit Conditions and International Trade during the Global Financial Crisis. Mimeo.

[22] Desai, Mihir, Fritz Foley, and Kristin J. Forbes (2008) Financial Constraints and Growth: Multinational and Local Firm Responses to Currency Depreciations. Review of Financial Studies 21 (6), 2857-2888.

[23] Eaton, Jonathan, Sam Kortum, Brent Neiman, and John Romalis (2009). Trade and the Global Recession. Mimeo.

[24] Gibson, John and Richard I. D. Harris (1996) Trade Liberalization and Plant Exit in New Zealand Manufacturing. Review of Economics and Statistics 78 (3), 521-529.

[25] Glick, R. and A. Rose (1999) Contagion and Trade: Why are Currency Crises Regional? Journal of International Money and Finance 18, 603-617.

[26] Görg, Holger and Eric Strobl (2003) Footloose Multinationals? The Manchester School $71,1-19$.

[27] Haddad, Mona, and Ann E. Harrison (1993) Are There Positive Spillovers from Direct Foreign Investment? Evidence from Panel Data for Morocco. Journal of Development Economics 42 (1), 51-74 
[28] Harrison, A. E., I. Love, and M. S. McMillian (2004) Global Capital Flows and Financing Constraints. Journal of Development Economics 75, 269-301.

[29] Helpman, Elhanan (1984) A Simple Theory of International Trade with Multinational Corporations. Journal of Political Economy 92 (3), pp. 451-471.

[30] Javorcik, Beata Smarzynska (2004) Does Foreign Direct Investment Increase the Productivity of Domestic Firms? In Search of Spillovers through Backward Linkages. American Economic Review 94 (3), 605-627.

[31] Lipsey, Robert E. (1978) The Creation of Microdata Sets for Enterprises and Establishments. Annales de l'INSEE 30-31, 395-422.

[32] Levchenko, Andrei, Logan Lewis, and Linda Tesar (2010) The Collapse of International Trade During the 2008-2009 Crisis: In Search of the Smoking Gun. IMF Economic Review 58 (2), 214-253.

[33] Markusen, James R. (1984) Multinationals, Multi-Plant Economies, and the Gains from Trade. Journal of International Economics 16 (3-4), pp. 205-226.

[34] Rajan, Raghuram G., and Luigi Zingales (1998) Financial Dependence and Growth. American Economic Review 88, 559-586.

[35] Rose, Andrew and Mark Spiegel (2010a) The Causes and Consequences of the 2008 Crisis: International Linkages and American Exposure. Pacific Economic Review 15 (3), 340-363.

[36] Rose, Andrew and Mark Spiegel (2010b) The Causes and Consequences of the 2008 Crisis: An Update. European Economic Review, forthcoming.

[37] Rosenbaum, P.R. and D.B. Rubin (1983) The Central Role of the Propensity Score in Observational Studies for Causal Effects. Biometrika 70(1), 41-55.

[38] Tong, Hui and Shang-Jin Wei (2009) The Composition Matters: Capital Inflows and Liquidity Crunch During a Global Economic Crisis. Review of Financial Studies, forthcoming. 
Table 1: Estimated Average Effect of Foreign Ownership

\begin{tabular}{lccc}
\hline \hline & $(1)$ & $(2)$ & $(3)$ \\
& Crisis & Non-crisis & Diff. \\
\hline Performance difference b/w & $0.03^{* * *}$ & $0.002^{*}$ & $0.028^{* *}$ \\
MNC subsidiaries and local matches & $(0.01)$ & $(0.001)$ & $(0.01)$ \\
Number of matched pairs & 43,513 & 43,513 & 43,513 \\
\hline \hline
\end{tabular}

Notes: This table reports MNC subsidiaries' average performance difference from their local matches in crisis and non-crisis periods. Performance is measured by the annual percentage change in sales. Propensity score matching is employed to identify the matches of MNC subsidiaries. Standard errors are bootstrapped with industry clustering and reported in the parentheses. ${ }^{* * *} \mathrm{p}<0.01,{ }^{* *} \mathrm{p}<0.05,{ }^{*} \mathrm{p}<0.1$.

Table 2: Estimated Average Effect of Foreign Ownership by Type of Production Linkages

\begin{tabular}{lccc}
\hline \hline & $(1)$ & $(2)$ & $(3)$ \\
& Crisis & Non-crisis & Diff. \\
\hline Performance difference: Horizontal & 0.02 & $0.002^{* *}$ & 0.018 \\
& $(0.013)$ & $(0.001)$ & $(0.01)$ \\
Performance difference: Vertical & $0.23^{* *}$ & -0.001 & $0.23^{* *}$ \\
& $(0.10)$ & $(0.01)$ & $(0.10)$ \\
Performance difference: Neither & 0.03 & 0.003 & 0.027 \\
& $(0.04)$ & $(0.002)$ & $(0.02)$ \\
\hline \hline
\end{tabular}

Notes: This table reports MNC subsidiaries' average performance difference from their local matches, by type of production linkages, in crisis and non-crisis periods. Performance is measured by the annual percentage change in sales. Propensity score matching is employed to identify the matches of MNC subsidiaries. Standard errors are bootstrapped with industry clustering and reported in the parentheses. ${ }^{* * *} \mathrm{p}<0.01,{ }^{* *} \mathrm{p}<0.05,{ }^{*} \mathrm{p}<0.1$. 
Table 3: Foreign Ownership and Establishment Performance: Production Linkages

\begin{tabular}{lcccc}
\hline \hline Dependent variable: & $(1)$ & $(2)$ & $(3)$ & $(4)$ \\
Performance difference & Crisis & Crisis & Non-crisis & Non-crisis \\
\hline Production linkages & $1.06^{*}$ & $0.96^{* *}$ & -0.04 & -0.03 \\
& $(0.62)$ & $(0.46)$ & $(0.05)$ & $(0.05)$ \\
Country FE & No & Yes & No & Yes \\
Number of matched pairs & 43,513 & 43,513 & 43,513 & 43,513 \\
R square & 0.02 & 0.05 & 0.00 & 0.00 \\
\hline \hline
\end{tabular}

Notes: This table examines the effect of production linkages on MNC subsidiaries' performance difference from their local matches during crisis and non-crisis periods. Performance is measured by the annual percentage change in sales. Standard errors are bootstrapped with industry clustering and reported in the parentheses. ${ }^{* * *} \mathrm{p}<0.01,{ }^{* *} \mathrm{p}<0.05,{ }^{*} \mathrm{p}<0.1$.

Table 4: Foreign Ownership and Establishment Performance: Production Linkages and Demand Shocks

\begin{tabular}{lccc}
\hline \hline Dependent variable: & $(1)$ & $(2)$ & $(3)$ \\
Performance difference & Crisis & Crisis & Crisis \\
\hline Production linkages & $1.81^{* *}$ & $1.20^{*}$ & $2.14^{* *}$ \\
& $(0.93)$ & $(0.70)$ & $(1.07)$ \\
x Host-country demand shocks & $4.26^{*}$ & & $4.45^{*}$ \\
& $(2.60)$ & & $(2.68)$ \\
x Home-country demand shocks & & 1.32 & 1.64 \\
& & $(2.07)$ & $(1.47)$ \\
Country FE & Yes & Yes & Yes \\
Number of matched pairs & 43,513 & 43,513 & 43,513 \\
R square & 0.05 & 0.05 & 0.05 \\
\hline \hline
\end{tabular}

Notes: This table examines the effect of production linkages and country demand shocks on MNC subsidiaries' performance difference from their local matches during the crisis. Performance is measured by the annual percentage change in sales. Standard errors are bootstrapped with industry clustering and reported in the parentheses. ${ }^{* * *} \mathrm{p}<0.01,{ }^{* *} \mathrm{p}<0.05,{ }^{*} \mathrm{p}<0.1$. 
Table 5: Foreign Ownership and Establishment Performance: Financial Linkages

\begin{tabular}{lcccc}
\hline \hline Dependent variable: & $(1)$ & $(2)$ & $(3)$ & $(4)$ \\
Performance difference & Crisis & Crisis & Non-crisis & Non-crisis \\
\hline Financial linkages & $4.67^{* *}$ & $4.62^{* *}$ & 0.06 & 0.06 \\
& $(2.26)$ & $(2.25)$ & $(0.24)$ & $(0.24)$ \\
Production linkages & & $0.95^{* *}$ & & -0.03 \\
& & $(0.51)$ & & $(0.05)$ \\
Country FE & Yes & Yes & Yes & Yes \\
Number of matched pairs & 43,513 & 43,513 & 43,513 & 43,513 \\
R square & 0.05 & 0.05 & 0.02 & 0.02 \\
\hline \hline
\end{tabular}

Notes: This table examines the effect of financial linkages on MNC subsidiaries' performance difference from their local matches during crisis and non-crisis periods. Performance is measured by the annual percentage change in sales. Standard errors are bootstrapped with industry clustering and reported in the parentheses. ${ }^{* * *} \mathrm{p}<0.01,{ }^{* *} \mathrm{p}<0.05,{ }^{*} \mathrm{p}<0.1$.

Table 6: Foreign Ownership and Establishment Performance: Financial Dependence

\begin{tabular}{lcccc}
\hline \hline Dependent variable: & $(1)$ & $(2)$ & $(3)$ & $(4)$ \\
Performance difference & Crisis & Crisis & Non-crisis & Non-crisis \\
\hline Financial dependence & $0.27^{*}$ & $0.27^{*}$ & $0.02^{* *}$ & $0.02^{* *}$ \\
& $(0.17)$ & $(0.17)$ & $(0.01)$ & $(0.01)$ \\
Production linkages & & $0.86^{* *}$ & & -0.04 \\
& & $(0.43)$ & & $(0.05)$ \\
Country FE & Yes & Yes & Yes & Yes \\
Number of matched pairs & 43,513 & 43,513 & 43,513 & 43,513 \\
R square & 0.05 & 0.05 & 0.02 & 0.02 \\
\hline \hline
\end{tabular}

Notes: This table examines the effect of financial dependence on MNC subsidiaries' performance difference from their local matches during crisis and non-crisis periods. Performance is measured by the annual percentage change in sales. Standard errors are bootstrapped with industry clustering and reported in the parentheses. ${ }^{* * *} \mathrm{p}<0.01,{ }^{* *} \mathrm{p}<0.05,{ }^{*} \mathrm{p}<0.1$. 
Table 7: Foreign Ownership and Establishment Performance: Financial Linkages and Financial Shocks

\begin{tabular}{lccc}
\hline \hline Dependent variable: & $(1)$ & $(2)$ & $(3)$ \\
Performance difference & Crisis & Crisis & Crisis \\
\hline Financial linkages & $3.28^{*}$ & $5.64^{* * *}$ & $4.17^{* *}$ \\
& $(1.83)$ & $(1.86)$ & $(1.95)$ \\
x Host-country financial shocks & $4.06^{* *}$ & & $4.64^{* * *}$ \\
& $(1.86)$ & & $(1.91)$ \\
x Home-country financial shocks & & $-1.51^{*}$ & $-1.54^{*}$ \\
& & $(0.91)$ & $(0.91)$ \\
Production linkages & $1.82^{* *}$ & $1.19^{* *}$ & $2.14^{* *}$ \\
& $(0.86)$ & $(0.61)$ & $(1.13)$ \\
x Host-country demand shocks & $4.32^{* *}$ & & $4.47^{*}$ \\
& $(2.17)$ & & $(2.32)$ \\
x Home-country demand shocks & & 0.97 & 1.23 \\
& & $(3.95)$ & $(3.95)$ \\
Country FE & Yes & Yes & Yes \\
Number of matched pairs & 43,513 & 43,513 & 43,513 \\
R square & 0.05 & 0.05 & 0.05 \\
\hline \hline
\end{tabular}

Notes: This table examines the effect of financial linkages and country financial shocks on MNC subsidiaries' performance difference from their local matches during the crisis. Performance is measured by the annual percentage change in sales. Standard errors are bootstrapped with industry clustering and reported in the parentheses. ${ }^{* * *} \mathrm{p}<0.01,{ }^{* *} \mathrm{p}<0.05,{ }^{*} \mathrm{p}<0.1$. 
Table 8: Comparison of Foreign and Domestic Production and Financial Linkages

\begin{tabular}{lcc}
\hline \hline Dependent variable: & $(1)$ & $(2)$ \\
Performance difference & Crisis & Crisis \\
\hline Foreign ownership & $0.18^{* * *}$ & $0.05^{* *}$ \\
& $(0.01)$ & $(0.02)$ \\
x Financial linkages & & $0.85^{*}$ \\
& & $(0.50)$ \\
x Production linkages & & $5.58^{* * *}$ \\
& & $(1.32)$ \\
Financial linkages & & $5.26^{* * *}$ \\
& & $(0.49)$ \\
Production linkages & & 0.17 \\
& & $(0.26)$ \\
Country FE & Yes & Yes \\
Number of matched pairs & 269,008 & 269,008 \\
R square & 0.04 & 0.05 \\
\hline \hline
\end{tabular}

Notes: This table examines the differential effect of foreign and domestic linkages on subsidiaries' performance difference from their local matches. Both foreign and domestically owned subsidiaries are included in the sample. Performance is measured by the annual percentage change in sales. Propensity score matching is employed to identify the matches of foreign and domestically owned subsidiaries. Standard errors are bootstrapped with industry clustering and reported in the parentheses. ${ }^{* * *} \mathrm{p}<0.01,{ }^{*} \mathrm{p}<0.05,{ }^{*} \mathrm{p}<0.1$. 
Table 9: The Effect of MNC Networks

\begin{tabular}{|c|c|c|c|c|}
\hline Dependent variable: & $(1)$ & $\overline{(2)}$ & $\overline{(3)}$ & $\overline{(4)}$ \\
\hline Performance difference & Crisis & Crisis & Non-crisis & Non-crisis \\
\hline Financial linkages & $\begin{array}{c}4.83^{* * *} \\
(1.76)\end{array}$ & $\begin{array}{c}4.97^{* * *} \\
(1.78)\end{array}$ & $\begin{array}{c}0.06 \\
(0.13)\end{array}$ & $\begin{array}{c}0.06 \\
(0.19)\end{array}$ \\
\hline Production linkages & $\begin{array}{c}0.93^{* *} \\
(0.59)\end{array}$ & $\begin{array}{c}0.91^{* *} \\
(0.40)\end{array}$ & $\begin{array}{l}-0.03 \\
(0.04)\end{array}$ & $\begin{array}{l}-0.03 \\
(0.05)\end{array}$ \\
\hline Network (country count) & $\begin{array}{c}0.003^{* *} \\
(0.001)\end{array}$ & & $\begin{array}{c}0.000 \\
(0.000)\end{array}$ & \\
\hline Horizontal network (country count) & $\begin{array}{c}0.002 \\
(0.004)\end{array}$ & & $\begin{array}{c}-0.0001 \\
(0.000)\end{array}$ & \\
\hline Network (revenue share) & & $\begin{array}{c}0.06^{*} \\
(0.03)\end{array}$ & & $\begin{array}{l}0.0002 \\
(0.002)\end{array}$ \\
\hline Horizontal network (revenue share) & & $\begin{array}{c}0.01 \\
(0.04)\end{array}$ & & $\begin{array}{c}0.001 \\
(0.003)\end{array}$ \\
\hline Country FE & Yes & Yes & Yes & Yes \\
\hline Number of matched pairs & 43,513 & 43,513 & 43,513 & 43,513 \\
\hline $\mathrm{R}$ square & 0.05 & 0.05 & 0.02 & 0.02 \\
\hline
\end{tabular}

Notes: This table examines the effect of MNC networks on MNC subsidiaries' performance difference from their local matches. Performance is measured by the annual percentage change in sales. Standard errors are bootstrapped with industry clustering and reported in the parentheses. $* * * \mathrm{p}<0.01,{ }^{* *} \mathrm{p}<0.05,{ }^{*} \mathrm{p}<0.1$.

Table 10: Foreign Ownership and Establishment Performance: Controlling for Correlations of Residuals within MNCs and within industries

\begin{tabular}{lcc}
\hline \hline Dependent variable: & $(1)$ & $(2)$ \\
Performance difference & Crisis & Non-crisis \\
\hline Financial linkages & $4.62^{* *}$ & 0.06 \\
& $(2.30)$ & $(0.25)$ \\
Production linkages & $0.95^{* *}$ & -0.03 \\
& $(0.52)$ & $(0.05)$ \\
Country FE & Yes & Yes \\
MNC and industry clusters & Yes & Yes \\
Number of matched pairs & 43,513 & 43,513 \\
R square & 0.05 & 0.02 \\
\hline \hline
\end{tabular}

Notes: This table controls for correlations of residuals between establishments owned by the same MNC and between establishments in the same industry. Cameron, Gelbach and Miller's (2006)'s multi-way clustering is employed. Standard errors are reported in the parentheses. $* * * \mathrm{p}<0.01, * * \mathrm{p}<0.05, * \mathrm{p}<0.1$. 
Table 11: Foreign Ownership and Establishment Performance: Controlling for MNC firm heterogeneity

\begin{tabular}{lcc}
\hline \hline Dependent variable: & $(1)$ & $(2)$ \\
Performance difference & Crisis & Non-crisis \\
\hline Financial linkages & - & - \\
& & \\
Production linkages & $1.28^{*}$ & -0.15 \\
& $(0.74)$ & $(0.09)$ \\
MNC firm FE & Yes & Yes \\
Number of matched pairs & 32,363 & 32,363 \\
R square & 0.18 & 0.15 \\
\hline \hline
\end{tabular}

Notes: This table controls for MNC firm heterogeneity in examining the effect of production and financial linkages on MNC subsidiaries' performance difference from their local matches. Performance is measured by the annual percentage change in sales. Standard errors are bootstrapped with industry clustering and reported in the parentheses. ${ }^{* * *} \mathrm{p}<0.01,{ }^{* *} \mathrm{p}<0.05,{ }^{*}$ $\mathrm{p}<0.1$. 